\title{
In Balans ?...!
}

Citation for published version (APA):

Zimmermann, L. J. I. (2005). In Balans ?...! Universiteit Maastricht. https://doi.org/10.26481/spe.20050415lz

Document status and date:

Published: 15/04/2005

DOI:

10.26481/spe.20050415lz

Document Version:

Publisher's PDF, also known as Version of record

\section{Please check the document version of this publication:}

- A submitted manuscript is the version of the article upon submission and before peer-review. There can be important differences between the submitted version and the official published version of record.

People interested in the research are advised to contact the author for the final version of the publication, or visit the DOI to the publisher's website.

- The final author version and the galley proof are versions of the publication after peer review.

- The final published version features the final layout of the paper including the volume, issue and page numbers.

Link to publication

\footnotetext{
General rights rights.

- You may freely distribute the URL identifying the publication in the public portal. please follow below link for the End User Agreement:

www.umlib.nl/taverne-license

Take down policy

If you believe that this document breaches copyright please contact us at:

repository@maastrichtuniversity.nl

providing details and we will investigate your claim.
}

Copyright and moral rights for the publications made accessible in the public portal are retained by the authors and/or other copyright owners and it is a condition of accessing publications that users recognise and abide by the legal requirements associated with these

- Users may download and print one copy of any publication from the public portal for the purpose of private study or research.

- You may not further distribute the material or use it for any profit-making activity or commercial gain

If the publication is distributed under the terms of Article $25 \mathrm{fa}$ of the Dutch Copyright Act, indicated by the "Taverne" license above, 
061 
In Balans ?...! 


\section{Colofon}

Basisontwerp en realisatie: Unigraphic, Universiteit Maostricht.

ISBN 90-5681-223-8

NUR 876

Alle rechten voorbehouden. Niets uit deze uitgave mag worden verveelvoudigd, opgeslagen in een geoutomotiseerd gegevensbestand of openbaar gemaakt, zonder voorafgaande schrifte. lijke toestemming van de auteur of uitgever. 


\section{$M G$ VAC 662}

\section{In Balans ?...!}

Inaugurele Rede

Uitgesproken bij de aanvaarding van het ambt van bijzonder hoogleraarschap in de Kindergeneeskunde. in het bijzonder in de Neonatologie.

15 april 2005

\section{Luc J.I. Zimmermann}

$\mathbf{U}$ 


$$
\begin{aligned}
& \text { PPN. } 279 \text { g23 \& } 13 \\
& \text { Uniwrsiteitsbibliotheek } \\
& \text { Universiturt biassticict } \\
& 65050
\end{aligned}
$$


Mijnheer de Rector Magnificus,

Leden van het College van Bestuur van de Universiteit,

Leden van het College van Toezicht,

Leden van de Raad van Bestuur van het Academisch Ziekenhuis,

Zeer gewaardeerde toehoorders,

Emma's zwangerschap was tot dan toe zonder problemen verlopen. Alle controles, ook de echo's waren prima geweest. Ze was de vorige middag naar het Academisch Ziekenhuis van Maastricht gekomen omdat ze harde buiken had. Omdat Emma pas net 25 weken zwanger was werd weeënremming gegeven, aanvankelijk met succes.

Om 03.00 uur's nachts zette de baring echter toch plots door en werd Sanne geboren, drieëneenhalve maand te vroeg. De assistent kindergeneeskunde en de neonatoloog waren net op tijd. Sanne ademde nauwelijks, was slap en zag paars-blauw. Wat nu?

Er is veel discussie over de grens warop een extreem vroeg geborene behandeld dient te worden. Enkele dagen eerder in de zwangerschap zouden we wellicht niet gestart zijn met behandelen maar bij 25 weken starten we in principe wel. Dit was's middags ook zo met de ouders besproken. Sanne krijgt een maskertje over mond en neus waardoor ademteugen met zuurstof worden gegeven. Hoeveel zuurstof eigenlijk? Zuiver zuurstof ...... om zo snel mogelijk zuurstof in het bloed te krijgen? Uit onderzoek weten we intussen dat te veel zuurstof erg schadelijk kan zijn. Daarom worden soms ademteugen met gewone lucht aangeraden. ${ }^{1}$ Hierover is nog geen definitieve uitspraak. We starten met zuiver zuurstof en Sanne's kleur begint mooi roze te worden, ze begint wat activiteit te tonen en ze begint goed door te ademen, zij het met moeite. Moeten we nu snel intuberen en mechanisch beademen? Welk type beademing dan? De beademingsmachines hebben tegenwoordig vrijwel onbeperkte mogelijkheden. Dit doet me denken aan deze reclame voor telefoons. Ze kunnen zoveel maar je kan er zelfs gewoon mee bellen. Met beademingsapparaten kan je zelfs gewoon beademen.

Mogelijk geeft enige ondersteuning met wat extra druk in de neus. zogenoemde CPAP, minder longbeschadiging. Dit laatste werd gegeven en Sanne werd opgenomen op de neonatale intensive care afdeling. Als beademing nodig was zouden we nu surfactant in de longen geven. Dit is een stof die te vroeg geboren baby's te weinig hebben waardoor longblaasjes dichtvallen en longproblemen ontstaan. Het is momenteel 
nog niet duidelijk of intuberen alléen om surfactant toe te dienen gunstig is. ${ }^{2}$ We kiezen ervoor om dit bij Sanne nu niet te doen. Ook op de volgende vragen hebben we geen goed antwoord:

Dienen we de ademhaling te stimuleren met Caffeine?3 Hoe snel moeten we voeding starten via de maagsonde? Is het gevaarlijk voeding te geven met nog een infuus in de navelvaten? Hoe snel kunnen we met de voeding opklimmen en in welke concentratie? Is het nuttig antibiotica te geven? Hoe hoog mag Sanne's koolzuurgehalte in het bloed oplopen voor we toch gaan beademen?4

Eigenlijk is het een wonder dat we zulke kleine baby's als Sanne met succes kunnen behandelen terwijl we met zulke essentiële vragen zitten. Alleen door doorgedreven onderzoek kunnen deze vragen op een goede manier worden opgelost.

Onderzoek kan op vele manieren bijdragen tot een betere zorg voor de patiënt.5

Soms lijkt een bepaalde behandeling een spectaculair resultaat te geven maar onderzoek vindt verrassend grote nadelen. Een dramatisch voorbeeld is de zuurstofbehandeling van te vroeg geboren baby's tientallen jaren geleden waardoor de overleving sterk verbeterde. Maar wat bleek? Vele van deze pasgeborenen waren later blind en studies toonden aan dat dit kwam door nadelige effecten van zuurstof op het netvlies. Zuurstof moest véél gematigder worden gegeven.

Soms is de relatie tussen onderzoek en verbetering van de zorg voor te vroeg geborenen heel duidelijk. Een voorbeeld is de behandeling van te vroeg geborenen met surfactant. Reeds in 1959 toonde Avery aan dat vele prematuren een tekort aan deze stof in de longen hebben waardoor hun longblaasjes dichtklappen met ademhalingsproblemen als gevolg. 6 Pas in de jaren ' 80 werd aangetoond dat het mogelijk was surfactant rechtstreeks in de longen van premature baby's toe te dienen met gunstig effect. Heel veel internationale studies volgden en toonden een verbetering van overleving van de vroeggeborenen met wel $40 \%$. De grootste stap voorwaarts in de recente geschiedenis van de neonatologie. In Nederland deden de neonatale centra mee aan deze studies. Het gevolg daarvan was dat meteen vanaf het begin iedereen goed bekend was met deze behandeling en deze nadien systematisch zonder vertraging werd ingevoerd.

Het komt ook vaak voor dat een klinische studie geen onderbouwing geeft voor de bestudeerde behandeling maar toch een aanzienlijke verbetering voor de patiëntenzorg oplevert. Ik geef $u$ ook hiervan graag een voorbeeld. Onderzoek toonde aan dat kankerpatiënten, dialysepatiënten 
en ook te vroeg geborenen minder bloed aanmaken door een tekort aan erythropoïetine, een hormoon dat de bloedaanmaak stimuleert, in sportmilieus beter bekend onder de naam epo.

Behandeling met dat hormoon is ingevoerd ter ondersteuning van sommige patiënten met kanker en nierproblemen. Ook bij te vroeg geborenen bleek epo de bloedaanmaak te stimuleren. Echter dit effect werd meer dan teniet gedaan doordat bij zieke vroeggeborenen zo dikwijls bloed werd afgenomen voor allerlei controles. Deze studies hebben er toe geleid dat we veel zuiniger zijn gaan omspringen met bloedafnames bij pasgeborenen.

Voor de individuele patiënt lijkt participatie in onderzoek een extra belasting en de patiënt is schijnbaar beter af zonder deelname aan onderzoek. Hij verwacht gewoon de beste behandeling die er is. Nog afgezien van het feit dat we, zoals boven uiteengezet, dikwijls de beste behandeling niet eens kennen, blijkt dat deelname aan klinisch onderzoek in het algemeen voor de patient gunstiger is dan geen deelname aan onderzoek.5. 7. 8 Deze paradox wordt wellicht verklaard door de nauwgezette protocollen en controles in goede klinische studies, nog los van de bestudeerde interventie zelf. Kwaliteit van patiëntenzorg stijgt door onderzoek in het algemeen en wellicht zelfs op niveau van de individuele patiënt.

Tot hiertoe heb ik geprobeerd het directe belang van patiëntgebonden onderzoek aan te geven.

Maar er is nog veel meer. De grootste ontdekkingen worden gemaakt in basaal wetenschappelijk onderzoek. De laatste jaren is er een enorme vooruitgang gemaakt in moleculaire biologie en celbiologie. Zo is het hele menselijke genoom in kaart gebracht en zijn vele nieuwe groeifactoren en ontstekingsfactoren gevonden. Dit zijn eiwitten die door cellen gemaakt en uitgescheiden worden en die vele effecten hebben. Ze zijn van belang bij alle processen in het lichaam. Het duurt steeds enige tijd vooraleer deze nieuwe bevindingen leiden tot nieuwe diagnosemogelijkheden of behandelingen in de kliniek. Hiervoor is translationeel onderzoek nodig, onderzoek dat de vertaalslag maakt van de nieuwe basaal wetenschappelijke bevindingen naar klinische toepassingen. 9 


\section{ONDERZOEK $\rightleftarrows$ PATIENTENZORG}

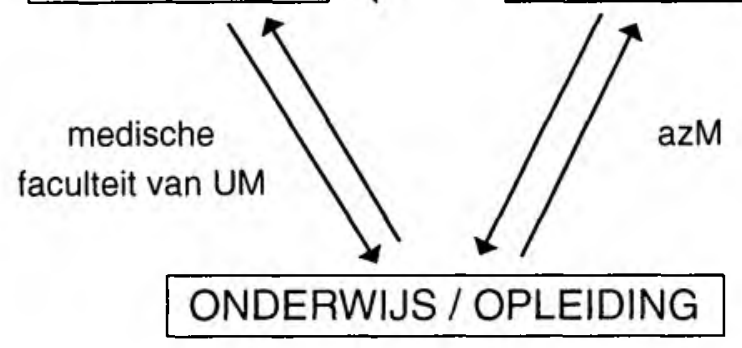

Dames en heren, de missie van een universitair medisch centrum is onderwijs en opleiding, onderzoek en patiëntenzorg. ${ }^{10-12}$ De medische faculteit staat hierbij voor onderwijs en onderzoek. Het academisch ziekenhuis levert topzorg, zorgt voor innovatie, en waarborgt de opleiding van specialisten en subspecialisten.

Daarnaast heeft het academisch ziekenhuis een werkplaatsfunctie voor de medische faculteit: dit wil eenvoudigweg zeggen dat het de patiënten levert voor onderwijs en klinisch onderzoek.

Het is duidelijk dat deze taken zeer verweven zijn met elkaar en dat goede afstemming nodig is. De hoofdtaken onderwijs, onderzoek en patiëntenzorg dienen in balans te zijn ten opzichte van elkaar. In praktijk staat deze balans echter omwille van vele redenen ernstig onder druk.

\section{COMMUNICERENDE VATEN}

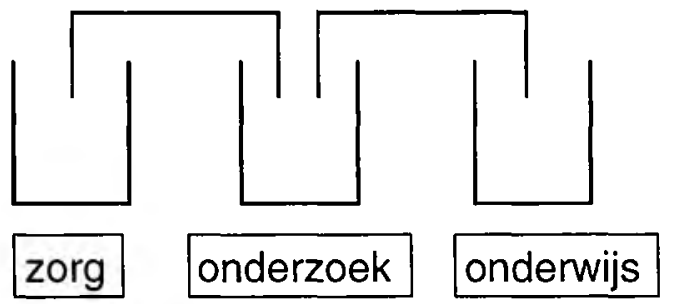


Het probleem kan verduidelijkt worden aan de hand van een model met communicerende vaten. ${ }^{10}$ Voor de 3 hoofdtaken zijn geldelijke middelen en mensen nodig. De gelden komen langs verschillende wegen binnen maar uiteindelijk gaat het in essentie om 1 grote pot met geld waaruit alles moet gebeuren. Hetzelfde is waar voor de academische medisch specialisten die alle 3 de taken dienen te vervullen. Omdat voor de grootste inkomsten, namelijk deze van de zorg. productieafspraken gemaakt zijn met de ziektekostenverzekeraars dienen deze te allen tijde geleverd te worden. Voor onderwijs zijn er afspraken gemaakt met het onderwijsinstituut in de vorm van te leveren onderwijsuren. Het is dus makkelijk te begrijpen dat in tijden van schaarste niet in de eerste plaats zorg en onderwijs maar vooral het onderzoek onder druk komt en vooral het klinisch gericht onderzoek..$^{\circ}$ Op langere termijn is dit echter nefast voor de kwaliteit van zorg en onderwijs.

Drie jaar geleden hielden de neonatologen in Rotterdam, waar ik toen werkte, gedurende een half jaar nauwkeurig bij hoeveel tijd ze besteedden aan elk van de hoofdtaken.

Dit liet zien dat $63 \%$ van de tijd aan patiëntenzorg besteed wordt, $20 \%$ aan onderwijs, $11 \%$ aan management en slechts $7 \%$ aan onderzoek. Een recente schatting in Maastricht leverde gelijkaardige cijfers op.

Ook de nationale Nivel enquête naar de benodigde capaciteit van kinderartsen in Nederland inventariseerde de tijdsbesteding. Deze van de neonatologen heb ik opgevraagd en ziet er als volgt uit:

Opnieuw is $60 \%$ patiëntgebonden tijd, $17 \%$ onderwijs en literatuurstudie en $11 \%$ management. De onderzoekstijd kwam op $12 \%$. Dit komt globaal overeen met onze Rotterdamse en Maastrichtse data. De tijd besteed aan onderzoek is ver beneden de streefwaarde van 25 tot $30 \%$.

Ook internationaal klinken noodkreten. Hier enkele titels uit het toonaangevende Britisch Medical Journal.

1. Resuscitating clinical research in the United Kingdom. ${ }^{3}$

2. Failure to support clinical research now will cost human lives later.14

3. Academic medicine: time for reinvention. ${ }^{5}$

Dit leidde er zelfs toe dat de Britisch Medical Journal oproept tot een internationale campagne om academische geneeskunde te promoten. ${ }^{16}$ [BMJ Publishing Group to launch an international campaign to promote academic medicine; please join us.] ${ }^{16}$

Gelukkig zien ook Nederlandse instanties het probleem. 17 Het ministerie van onderwijs, cultuur en wetenschappen, publiceerde "Wie oogsten 
wil, moet zaaien".18 De Raad van Medische Wetenschappen van de Koninklijke Nederlandse Academie van Wetenschappen (KNAW) stelt "binnen de raad bestaat ernstige zorg over het huidige financieringsbeleid van (bio)medisch wetenschappelijk onderzoek en de consequenties van dit beleid voor het kwalitatief hoog medisch onderzoeksniveau in de toekomst"19 en ook "Nederland investeert vergeleken met het buitenland relatief weinig in wetenschappelijk onderzoek. Het is de taak van de universitaire sector om ervoor te zorgen dat een groot deel van de politiek zich van het belang van funderend onderzoek bewust wordt". 10

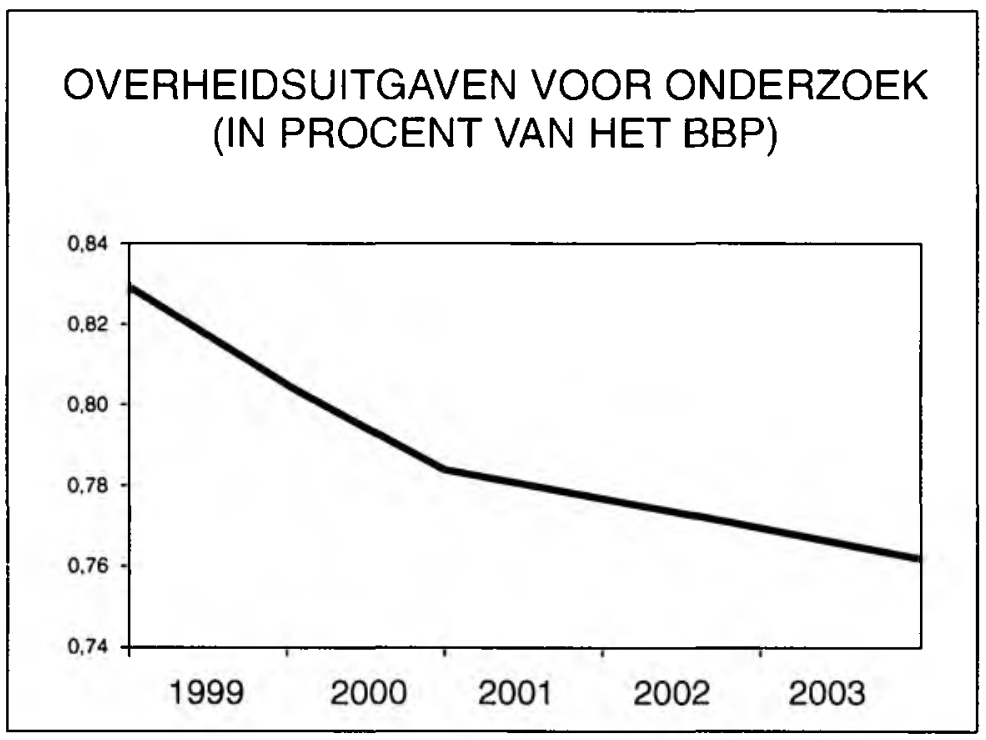

De grafiek toont het dalende budget voor onderzoek vanuit de Nederlandse overheid als percentage van het Bruto Binnenlands pro$\operatorname{duct}(B B P) .{ }^{18}$

Wat dient er in elk geval te gebeuren?

1. Er moet meer geld voor onderzoek beschikbaar komen.9. 10

2. Binnen beschikbare middelen en menskracht dient de balans onderzoek, onderwijs en patiëntenzorg bewaakt te worden.

3. In de nieuwe financieringssystematiek op basis van diagnose- behandelcombinaties oftewel DBC's dienen andere tarieven gehanteerd te worden voor academische ziekenhuizen. 
4. De samenwerking tussen basaal wetenschappelijk onderzoek en klinisch onderzoek moet versterkt worden.9.17

5. Informatietechnologie dient dringend uitgebouwd te worden. Klinische databases zijn nodig.9.17

6. Klinisch gericht onderzoek dient naast de klassieke beoordeling op inhoudelijke kwaliteit zoals impact factor van tijdschriften ook beoordeeld te worden op zijn bijdrage aan verbetering van de klinische zorg. ${ }^{19}$

7. Het belang van onderzoek voor de kwaliteit van zorg dient aan de maatschappij en de politiek duidelijk gemaakt te worden.10.17

Craag wil ik nu wat meer inhoudelijk ingaan op het onderzoek vanuit de neonatologie in Maastricht.

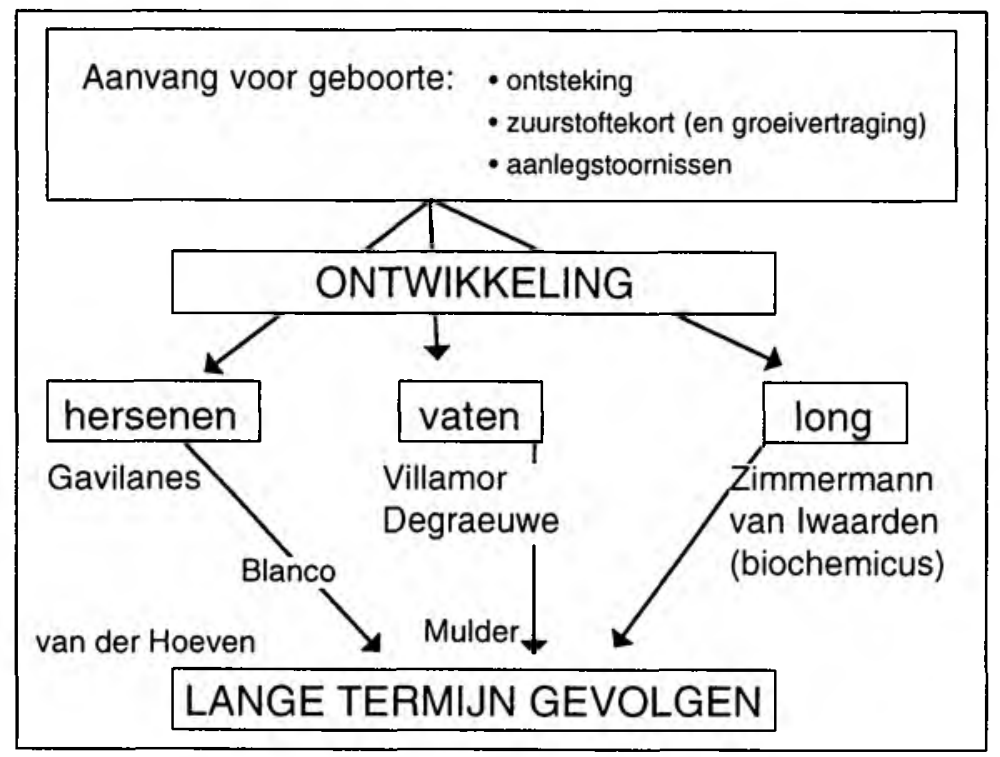

Dit onderzoek heeft noodzakelijkerwijs enkele bijzondere kenmerken:

- de ontwikkeling van de organen is nog niet voltooid, zeker niet bij te vroeg geborenen. Daarom is het noodzakelijk dat ons onderzoek aansluit bij andere basaal wetenschappelijk georiënteerde laboratoria die ontwikkeling bestuderen. Vanuit het onderzoeksinstituut GROW en vanuit de faculteit worden hiertoe stappen ondernomen. 
- Verstoring van deze ontwikkeling gebeurt heel vaak reeds vóór de geboorte door ontsteking van placenta en vliezen, zogenaamde chorioamnionitis, door zuurstoftekort, door groeivertraging voor de geboorte of door aanlegstoornissen, soms erfelijk bepaald. We zullen daarom werken aan een betere aansluiting van ons onderzoek bij dat van de gynaecologie-verloskunde en erfelijkheid.

- Uit de klinische praktijk van de neonatologie blijkt dat hersenschade en longschade de meest frequente lange termijn problemen geven. Recente inzichten wijzen erop dat de vaatontwikkeling een zeer belangrijke speler is.

- Verstoring van de normale ontwikkeling heeft gevolgen voor de lange termijn, soms ernstig, soms levenslang. Daarom is langdurige follow-up van patiënten nodig.

Het schema toont met welk deel van het onderzoek mijn collegae neonatologen zich bezighouden.

In het kort wil ik het onderzoek naar neonatale longschade ${ }^{21}$ beschrijven dat ik samen met Freek van Iwaarden vorm geef. Dit onderzoek bouwt verder op de expertise en resultaten die we in Rotterdam verkregen hebben. Graag wil ik hiervoor Freek bedanken.

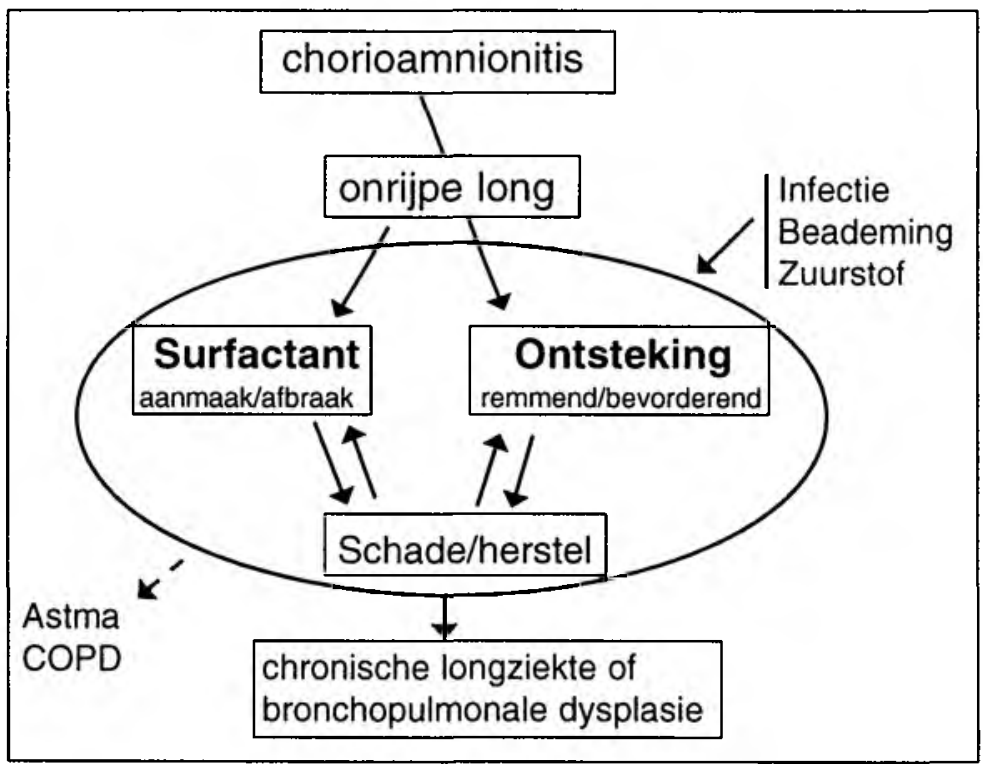


Bij placenta onderzoek van Sanne bleek dat er een ontsteking was van de vliezen, een zogenaamde chorioamnionitis. Dit was wellicht de oorzaak van de vroeggeboorte. Daardoor werd Sanne met onrijpe longen geboren. Hoewel de ademhalingsproblemen aanvankelijk mild waren moest Sanne na 5 dagen toch beademend worden toen ze een infectie in het bloed kreeg. De longfoto verslechterde hierbij progressief en Sanne raakte slechts na 15 dagen opnieuw van de beademing af, maar bleef langdurig zuurstof nodig hebben tot de leeftijd van 3 maanden. Rond die tijd zou ze normaal geboren worden. Door deze ademhalingsproblemen groeide Sanne minder goed. Na ontslag werd ze in het eerste levensjaar nog 3 keer opgenomen met longproblemen bij een verkoudheid. Sanne vertoont een typisch beeld van een milde vorm van bronchopulmonale dysplasie, een chronische longziekte na een premature geboorte. ${ }^{22,23}$ Bij Sanne begon de ontsteking in de longen reeds voor de geboorte. ${ }^{24}$ Deze werd versterkt door een infectie en door beademing en zuurstof. 23 Hierdoor werd het surfactantmetabolisme verstoord. 25,26 Dit alles leidde tot longschade in de reeds on rijpe longen.

In ons onderzoek staat de driehoek ontsteking, surfactant en schade/ herstel in de long centraal. We bestuderen hoe deze 3 elementen elkaar beïnvloeden en kunnen leiden tot bronchopulmonale dysplasie. Omdat de driehoek surfactant-ontsteking-schade/herstel ook een rol speelt bij grotere kinderen zoals bij astma en bij volwassenen zoals bij chronische bronchitis of COPD ben ik blij dat we een gemeenschappelijk laboratorium voor ontsteking in de humane long kunnen opzetten samen met de afdeling longziekten en de afdeling kinderlongziekten. Graag dank ik de Raad van Bestuur hiervoor.

Surfactant is een stof met als belangrijkste functie het openhouden van de longblaasjes. Prematuren hebben door longonrijpheid een tekort aan surfactant en daardoor dikwijls longproblemen. De hoeveelheid surfactant wordt bepaald door de balans tussen aanmaak en afbraak. Om dit te bestuderen hebben we meerdere nieuwe methoden ontwikkeld. Twee ervan wil ik kort bespreken.

In baby's bestuderen we de aanmaak van surfactant door via een infuus speciaal gemerkte voedingsstoffen toe te dienen. Voor kenners: de merker bestaat uit stabiele isotopen. De inbouw van deze merkers in nieuw gevormde surfactant is een goede maat voor surfactantaanmaak. ${ }^{27}, 28$ Deze nieuwe techniek die ik samen met hooggeleerden Sauer en Carnielli ontwikkeld heb heeft ons internationale bekendheid gegeven. Ik dank Virgilio voor de langdurige vruchtbare samenwerking. 
In celkweken en proefdieren kunnen we de opname van surfactant in de cellen bestuderen door het te merken met een fluorescerende stof. 29 Zowel bij pasgeborenen als in celkweken en proefdieren zal de invloed van ontstekingsfactoren en longschade op surfactant aanmaak en afbraak bestudeerd worden.

De balans tussen ontstekingsbevorderende en ontstekingsremmende factoren zal ook bestudeerd worden bij pasgeborenen met longproblemen 30 en in proefdieren en celkweken. Bij beademende pasgeborenen wordt regelmatig slijm uit de beademingsbuis uitgezogen. Dit slijm kan gemakkelijk opgevangen worden en geanalyseerd. Hierin kunnen we de ontstekingsfactoren meten 30.31 en hun effect op cellen in kweek bestuderen. Nieuwe factoren die van belang zijn bij longschade kunnen opgespoord worden door volledige eiwitprofielen te analyseren met nieuwe moderne technieken samengevat onder de naam proteomics.32. 33

Voor de studie van de balans tussen schade en herstel van de longen zijn verschillende modellen met celkweken beschikbaar.

Een voorbeeld:

We kweekten longepitheelcellen in een schaaltje tot ze de bodem van het schaaltje volledig bedekten. Dan maakten we een defect in de cellaag door erin te krassen. Deze cellaag zal nu terug dichtgroeien.

\section{Sluiting van celdefect in de aanwezigheid van slijm van premature baby's}

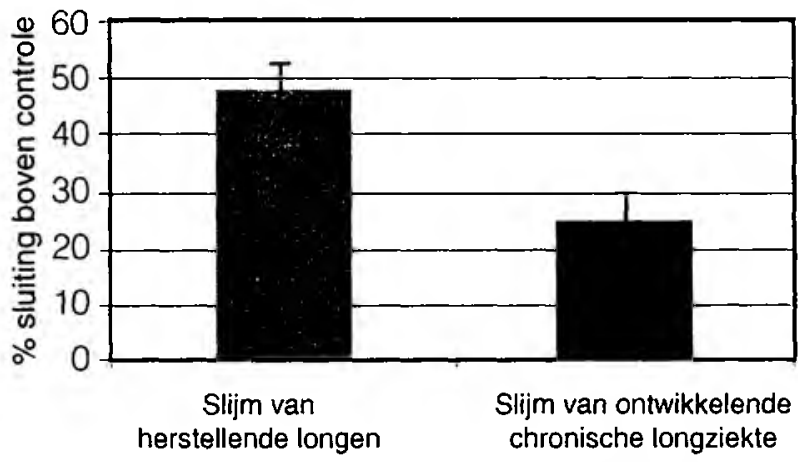


We vonden dat verdund slijm van baby's op de $2^{\mathrm{e}}$ tot de $4^{\mathrm{e}}$ levensdag die een goed herstel van de longproblemen hadden dit dichtgroeien stimuleerde. Slijm van baby's die echter een chronische longziekte ontwikkelden stimuleerde dit dichtgroeien duidelijk minder. De conclusie is dat celherstel in een zeer vroege fase, namelijk de eerste levensdagen, gestoord is bij baby's die nadien chronische longziekten ontwikkelen. Welke precieze factoren hierin een rol spelen zal nu onderzocht worden. Tevens zullen we kijken naar de interactie tussen cellen door meerdere type longcellen tegelijk te kweken. 34

Als we weten welke factoren op een gunstige manier kunnen beïnvloed worden in kweek zal dit terug naar de kliniek moeten vertaald worden. Hierin staat de wetenschap nog relatief zwak. Met meerdere onderzoeksgroepen in Maastricht en samen met verschillende neonatologen in het land wil ik daarom onderzoeken of het kan om een diermodel voor longschade bij prematuren op te zetten. Hierin kunnen de nieuwe behandelingen getest worden, alvorens ze bij patiënten toe te passen.

Tenslotte zullen nieuwe mogelijke behandelingen grondig moeten bestudeerd worden bij onze patiënten zelf. In Nederland hebben de 10 neonatale centra een goede band met elkaar en de hoofden en afgevaardigden komen regelmatig samen in een vergadering genoemd Neoned. Zo ook zijn we vandaag samengekomen. Al een tijdje praten we daar over het komen tot een onderzoeksnetwerk voor gemeenschappelijke klinische multicenter studies, zoals in de V.S. bestaat. We moeten er nu echt werk van gaan maken.

\section{Patiëntenzorg in de neonatologie}

I $\mathrm{k}$ wil het nu met $\mathrm{u}$ hebben over enkele actuele onderwerpen in de zorg voor pasgeborenen waarbij we telkens moeten balanceren tussen 2 polen.

Een eerste balans is deze tussen overleven en kwaliteit van leven.

Het is duidelijk dat de neonatologie in zijn beginfase 25-30 jaar geleden erg gericht was op het verbeteren van op overleving van te vroeg geboren baby's. Wetenschappelijke en technische vooruitgang hebben dit mogelijk gemaakt. Vooral in de jaren ' 90 werd het besef steeds groter dat overleven alleen niet genoeg was. Kwaliteit van leven kreeg een toenemend belang. Daardoor ontstaat wel een ethisch dilemma dat vragen 
opwerpt rond het starten van behandeling, het staken van behandeling en zelfs het actief beëindigen van het leven in uiterste gevallen.

Enkele jaren geleden kwamen meer en meer neonatale centra in Nederland ervan terug om pasgeboren baby's bij een zwangerschapsduur van 24 weken, dit is $31 / 2$ maand te vroeg, systematisch actief te behandelen. Uiteindelijk deed geen enkel centrum dit meer waarbij Nederland wel een uitzonderingspositie inneemt. Deze beslissingen waren en zijn gebaseerd op een laag percentage overleving maar vooral op een hoog percentage handicaps en problemen. Recente studies uit verschillende landen bevestigen dit. De meest bekende recente studie is de Britse Epicure studie uit de NEJM die uitvoerig in de pers besproken is. 35 . 36 Ook pasgeborenen van 25 weken hebben nog zeer veel problemen en dit blijft dus een grijs gebied waarin individuele beslissingen zullen moeten genomen worden. De Nederlandse neonatologen zijn bezig samen met hun collega's uit de verloskunde tot een verfijning van de afwegingen te komen en ik wil dan ook niet vooruitlopen op de nieuwe afspraken die gemaakt zullen worden. Toch enkele belangrijke punten:

1. Een multidisciplinaire follow-up tot op oudere kinderleeftijd en liefst langer, van alle extreem vroeg geborenen dient te gebeuren. Momenteel is de afspraak tot 8 jaar maar dit gebeurt omwille van beperkte financiële middelen nog in vrijwel geen van de 10 neonatale centra. Dit dient dringend geregeld te worden. De data dienen in een goed geregelde nationale database te komen gekoppeld aan de verloskundige en neonatale data.

2. De neonatale centra zullen op regelmatige basis alle internationale gegevens samenvatten en bespreken.

3. Andere factoren dan alleen maar de zwangerschapsleeftijd zullen mee bepalen of een behandeling gestart wordt. Het past in de Nederlandse cultuur de ouders ook beter te informeren over de afwegingen en hun mening mee te wegen in de beslissing.

4. Ik blijf er voorstander van wel een grens te stellen aan de behandeling voor extreem vroeg geborenen.

5. Het is belangrijk te onderzoeken wat de maatschappij vindt van onze afwegingen. Voor welk percentage overleving en met welke 
mogelijke gevolgen voor later is men bereid welke prijs te betalen? Hierbij staat prijs zeker niet alleen voor geld maar ook voor intensive care behandeling en nabehandeling met alle nadelen ervan voor de pasgeborenen en de ouders.

In Nederland en België wordt over het algemeen aanvaard dat het staken van intensive care behandeling een optie is bij een zeer slechte prognose wat betreft kwaliteit van leven. De ernst van de behandeling staat dan niet meer in balans met de verwachte uitkomst ervan. Reeds geruime tijd is er veel discussie over de toelaatbaarheid van actieve levensbeëindiging bij pasgeborenen. In zeldzame gevallen kan de arts bij een zeer slechte prognose en daarbij onbehandelbaar uitzichtloos lijden in gewetensnood komen. De balans tussen het bewaren van het leven en het zorgen voor een menswaardig bestaan, in dit geval het bestrijden van lijden lijkt dan verstoord. Recent heeft collega Verhagen uit Groningen een protocol opgesteld waarin de zorgvuldigheidseisen staan waaraan zou moeten voldaan worden in gevallen waar actieve levensbeëindiging bij pasgeborenen overwogen wordt. Het is bekend onder de naam "Gronings protocol".37 Deze werkwijze heeft veel kritiek gekregen in het buitenland. Twee dingen dienen m.i. te gebeuren:

1. Een bredere discussie binnen onze beroepsgroep en met alle betrokken beroepsgroepen zou moeten leiden tot een landelijk protocol waarbij het Cronings protocol als uitgangspunt kan gebruikt worden. Naast zorgvuldigheidseisen dient ook het begrip onbehandelbaar en uitzichtloos lijden uitgewerkt te worden.

2. Er is door de politiek reeds lang toegezegd dat er een landelijke multidisciplinaire toetsingscommissie zou komen voor actieve levensbeeindiging bij pasgeborenen. Hierdoor wordt de toetsing inhoudelijk beter. Anderzijds dient dit te leiden tot een betere aanmelding van de gevallen. In Nederland worden op dit ogenblik, zoals ook in andere landen, de meeste gevallen niet gemeld uit angst voor gerechtelijke vervolging.

Een tweede balans in de zorg is deze tussen geld en kwaliteit van zorg oftewel de prijs/kwaliteit verhouding. Ik geef u even een voorbeeld van hoe moeilijk keuzes kunnen zijn wanneer men rekening moet houden met prijs en kwaliteit. Er is duidelijk nog geen volledige integratie voor een universitair medisch centrum. Het toiletpapier in de medische faculteit is meer luxueus dan dat in het ziekenhuis. Sinds de besparingen vorig 
jaar zijn we in het stafgebouw overgegaan op een grijzere variant.

Omdat de uitgaven in de gezondheidszorg blijven stijgen wordt de vraag naar de betaalbaarheid ervan steeds actueler. Door besparingen wordt zowel landelijk als in het azM de nadruk sterk gelegd op productie in termen van aantal opnames, dagbehandelingen en nieuwe polikliniek patiënten. De nieuwe vorm van financiering door Diagnose Behandelcombinaties zal concurrentie bevorderen met de bedoeling de prijzen van de zorg in toom te houden. Dit werkt echter in de hand dat ziektekostenverzekeraars en dus noodzakelijkerwijs ook ziekenhuizen vooral gefocust zijn op kosten en niet op kwaliteit. In de V.S. zijn hiermee slechte ervaringen opgedaan. Uiteraard bestaat dit spanningsveld niet alleen in de gezondheidszorg.

Kijk even mee naar de business strategie van topvoetbalclub Manchester United. "Manchester United's ambition to be the most successful team in football will be achieved by developing a successful and sustainable business. To this end, the football and commercial operation of Manchester United work hand-in-hand. There really is "only one United". Concurrentie in voetbal gaat om voetbalresultaat. Dit is ook voor Manchester United de eerste prioriteit, maar wordt ontersteund door het verkrijgen van financiële middelen. Bij meer voetbalsucces stromen meer middelen binnen en omgekeerd. Een evenwichtige balans.

In de gezondheidszorg dient kwaliteit ook bovenaan te staan. Betaling dient dan ook afgerekend te worden op basis van kwaliteit en niet alleen op basis van aantal handelingen.

Als er concurrentie moet komen dient deze dan ook primair op basis van kwaliteit gevoerd te worden en niet op basis van kosten. $3^{8}$ Dit betekent natuurlijk wel dat kwaliteit van zorg moet gemeten kunnen worden. Het ministerie van VWS heeft het belang hiervan ingezien en publiceerde eind 2002 het rapport: "Bakens zetten: naar een Nederlands raamwerk van prestatie-indicatoren voor de gezondheidszorg". 39 Hierbij wordt het managementinstrument de Balanced Score Card als basis gebruikt. Zorgsystemen worden beoordeeld vanuit 4 perspectieven die zoals de naam het zegt in balans zijn met elkaar. 


\section{Balanced Scorecard}

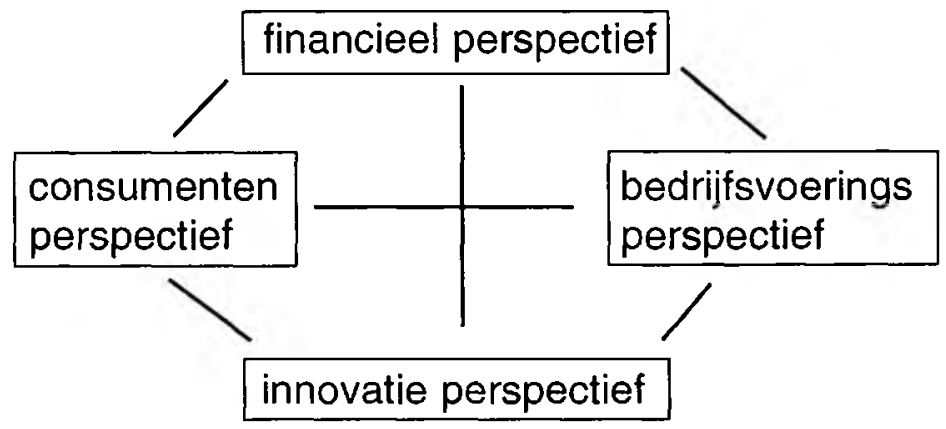

Een financieel perspectief, een bedrijfsvoeringperspectief, een innovatieperspectief (dit is nog belangrijker in academische ziekenhuizen) en een consumentenperspectief. Graag wil ik hier van de gelegenheid gebruik maken om zijn medecursisten en docenten in de opleiding tot master of management te Utrecht te danken voor de inspiratie en de stimulerende discussies.

Ook in een nieuw CBO rapport over intensive care worden suggesties gedaan voor kwaliteitsparameters. Ik wil deze graag toepassen op de neonatologie en enkele van onze verbeterprojecten daarbij aangeven:

De parameters worden ingedeeld in 4 resultaatgerichte categorieën:

1. Procesmatige verbeteringen en patiëntgerichtheid

- Betere coördinatie en individualisering rond de patiënt: zoals projecten voor betere pijnbestrijding, meer individuele aanpak en stressreductie, videobegeleiding van ouders

- Goede afstemming tussen vele disciplines en met regionale ziekenhuizen

- Zorglijnen ontwikkelen die starten prenataal en doorlopen naar het grotere kind

- Verdere inrichting van informatietechnologie zoals datamanagement, voorschrijfsystemen en elektronische dossiers 
2. Opnames-weigeringen-transporten

- Intensive care weigeringen dienen tot $<5 \%$ gereduceerd te worden

- Prenatale verwijzing van prematuren dient verder verbeterd te worden

- Een target voor aantal IC opnames wordt afgesproken en IC capaciteit erop aangepast

- Duidelijkere afbakening van $2^{\mathrm{e}}$ lijn en $3^{\mathrm{e}}$ lijn functie

3. Vermindering van complicaties en medische fouten

- We nemen deel aan het landelijk Neosafe project: goede registratie, analyse en terugkoppeling van alle incidenten en bijna incidenten.

- Infectieregistratie en -preventie

4. Volgen en verbeteren van outcome

- Mortaliteit en korte termijn morbiditeit (intracraniële bloedingen, chronische longziekte, en andere problemen)

- Verder opzetten van multidisciplinair follow-up programma tot 5 jaar en daarna tot 8 jaar volgens landelijke richtlijnen.

- Opzetten van multidisciplinaire poli's voor kinderen met neurologische of audiologische problemen

- Ethische discussiefora rond starten en staken van behandeling

De kwaliteit van zorg van een afdeling neonatologie is sterk afhankelijk van de toewijding en professionaliteit van de verpleging en andere medewerkers. Ik wil u hier allen hartelijk voor danken.

Het derde element in verband met de patiëntenzorg draait rond integrale ketenzorg: "de patiënt centraal". Concreet worden vanaf volgend jaar in het azM nieuwe clusterindelingen gehanteerd, zogenoemde "Resultaat verantwoordelijke eenheden". Zoals net gezegd hoop ik dat "resultaat" ook hier niet alleen financieel bedoeld zal worden. Ik ben enthousiast over de nieuwe te vormen eenheid "Erfelijkheid. Voorplanting en het Kind", afgekort EVK waarin de hele zorgketen van preconceptiezorg over zwangerschap, geboorte tot het oudere kind zal vertegenwoordigd zijn. Hierin worden afdelingen of delen van afdelingen samengebracht die rond dezelfde patiënten werken. Specifieke zorglijnen rond bepaalde patiëntengroepen zullen hierin ontwikkeld worden. Een goed voorbeeld is de zorg rond een bepalde aangeboren 
afwijking zoals spina bifida (of open rug) waarbij de vele betrokken medisch specialisten en andere zorgverleners van prenataal tot aan de kinderleeftijd een continuüm vormen. In dergelijke zorglijnen zal niet enkel het academisch ziekenhuis moeten worden betrokken maar waar nodig alle betrokken zorgverleners in de hele regio. Omdat de verloskunde en neonatologie vanuit het ministerie per definitie een bepaalde regio verzorgen zal samenwerking over de hele linie van preventieve gezondheidszorg tot derde lijn beter dienen te worden gestructureerd. Een belangrijke aanzet hiertoe werd gemaakt door recent overleg met consultatiebureau en jeugdgezondheidszorg organisaties uit onze regio en door de invoering van een transmuraal zorgcentrum voortplanting. Een vergaande samenwerking met de regionale ziekenhuizen in Limburg dient uitgewerkt te worden. Ook wat betreft logistiek kan dit grote voordelen opleveren. Het is nu utopie, maar wellicht denkbaar dat in de toekomst uit een database van alle zwangeren in Limburg voorspeld wordt wanneer piekmomenten op de afdeling neonatologie zullen optreden.

Omdat heel veel klinische spelers rond ontwikkeling namelijk van preconceptie tot het grotere kind in deze resultaat verantwoordelijke eenheid een rol zullen spelen zou ik het een gemiste kans vinden als verdere aansluiting bij het basaal wetenschappelijk onderzoek rond ontwikkeling niet plaats zou vinden. Klinisch onderzoek rond ontwikkeling dient de link te vormen.

Als laatste wil ik kort iets zeggen over onderwijs en opleiding.

Dit is eigenlijk de meest authentiek academische taak.40-43 Hoewel de universiteit van Maastricht bekend staat om zijn onderwijsvernieuwing op het gebied van probleemgestuurd onderwijs wordt het geven en organiseren van onderwijs slechts matig gewaardeerd. Weliswaar is er een redelijke personele compensatie maar in tegenstelling tot onderzoek wordt het geven van onderwijs in de loopbaanontwikkeling van minder belang gevonden. 44 Betere instrumenten ter beoordeling van onderwijsprestaties dienen ontwikkeld te worden. 44

In de opleiding van arts tot kinderarts, evenals in alle andere opleidingen, staan grote veranderingen voor de deur. Kernwoorden hierbij zijn competentiegericht, continue toetsing, docent professionalisering. Deze veranderingen zijn essentieel om de belangrijke academische taak van opleiding opnieuw een vooraanstaande plaats te geven. Maar natuurlijk geldt voor opleiding ook de theorie van de communicerende vaten. Meer druk op de patiëntenzorg levert minder tijd op voor opleiding, waar juist 
meer tijd zal gevraagd worden.41.43 Of omgekeerd, meer tijd nodig voor opleiding dient gecompenseerd te worden om niet ten koste te gaan van patiëntenzorg of onderzoek.

Omdat enerzijds het aantal opleidingsassistenten zal teruglopen en anderzijds de tijd van assistenten in opleiding die ze aan zorg kunnen besteden zal afnemen, zal ook hier een oplossing voor gevonden moeten worden. Aan de landelijke norm van 0,48 assistent per neonataal intensive care bed wordt al lang niet voldaan. De logische oplossing is het opleiden en aanstellen van nurse practitioners of physician assistents. Dit zijn in principe neonatale intensive care verpleegkundigen die na een verdere master opleiding medische taken kunnen verrichten. Hiermee zijn in sommige centra in Nederland en vooral in het buitenland in de neonatologie goede ervaringen opgedaan.

Dames en heren,

Maastricht werd gekozen tot beste stad van Nederland, onze universiteit en ook ons academisch ziekenhuis kwamen in enquẽtes als beste naar voren. Natuurlijk ben ik daar trots op. Ik weet niet wat de waarde is van dergelijke enquêtes, maar ik weet wel zeker dat we in de toekomst kwaliteit in zorg, onderwijs en onderzoek objectiever zullen moeten kunnen meten en bewaken, anders gaan we kapot aan uitsluitend financieel gerichte prikkels en concurrentie. De missie van het azM "vernieuwend in zorg en leren" is uitdagend maar kan alleen waargemaakt worden als de balans onderzoek, onderwijs en patiëntenzorg in evenwicht gehouden wordt. Daarom is het ook essentieel snel te komen tot de vorming van een universitair medisch centrum ${ }^{10}, 12$ waarbij medische faculteit en academisch ziekenhuis echt één organisatie vormen en de incorporatie van de faculteit gezondheidswetenschappen een plus vormt. 


\section{Dankwoord}

\section{Dank aan alle medewerkers in}

\section{Leuven}

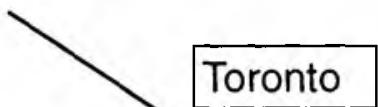

\section{Rotterdam}

\section{Maastricht}

Bijna aan het einde van mijn rede gekomen wil ik graag een woord van dank uitspreken. Sommigen heb ik in de loop van mijn verhaal bedankt.

De leden van het College van Bestuur en van het College van Toezicht, de medische faculteit, de Raad van Bestuur en de Annadal Stichting wil ik danken voor het in mij gestelde vertrouwen. Ik zal mijn uiterste best doen de verwachtingen waar te maken.

Hooggeleerden Eggermont en Devlieger, Beste Efrem en Hugo, jullie hebben mij een zeer goede opleiding gegeven in Leuven en het is aan jullie enthousiasme en expertise te danken dat ik neonatologie wilde gaan doen.

Hooggeleerden Smith en Post, Beste Barry en Martin, ik heb een geweldige tijd gehad in Toronto en daarbij vooral veel geleerd. Martin, jouw drive in het onderzoek werkt aanstekelijk. Je bent een geweldige mentor.

Hooggeleerde Sauer, Beste Pieter, jij hebt me de kansen gegeven me na mijn opleiding verder te ontplooien. Als promotor en "baas" heb je me de weg gewezen en tot zelfstandigheid gebracht.

Hooggeleerde Tibboel, Beste Dick, eerst als mijn medepromotor, later als onderzoekspartner hebben we veel samen gedaan. Hartelijk dank.

Hooggeleerden Büller en Van der Heyden, Beste Hans en Bert, ik wil 
jullie en via jullie alle medewerkers van Rotterdam bedanken voor de fijne tijd gedurende 11 jaar. Ik wens jullie zelf ook het allerbeste met jullie nieuwe baan. Speciaal wil ik mijn directe collegae danken in de neonatologie in Rotterdam voor de vele jaren samen.

Hooggeleerde Blanco, Beste Carlos, het vertrouwen dat jij in mij stelde en nog stelt is hoog. Ik hoop dat ik, wel op mijn eigen manier, een waardige opvolger zal zijn voor jou. De afgelopen 2 jaar heb je mij toenemende verantwoordelijkheid gegeven in een afdeling die jij hebt opgebouwd. Ik ben je zeer dankbaar.

Hooggeleerde Donckerwolcke, Beste Raymond, ook jou dank ik voor het grote vertrouwen en de mogelijkheden die je me geeft. Via jou wil ik de hele vakgroep kindergeneeskunde met al zijn medewerkers danken voor de fijne manier waarop ik ontvangen ben.

Pieter, Mark, Danilo. Twan en Eduardo, ik heb aan jullie geweldige collega's.

Tenslotte degenen die jullie straks echt moeten feliciteren.

Mijn ouders, mammie en pappie, jullie hebben er voor gezorgd dat ik steeds kon doen wat ik echt wilde en hebben me daarbij altijd enorm gesteund.

Dries, Wim en Hanne, als echte Rotterdammers was de stap naar Maastricht niet gemakkelijk. Ik vind het fijn dat jullie het toch aanvaard hebben en hoop dat jullie in de toekomst een goede balans vinden tussen Limburg en het westen van het land.

Lieve Moniek, zonder jou was dit alles nooit mogelijk geweest. Ik dank je voor de niet aflatende steun.

Geachte toehoorders, ik dank $u$ voor uw belangstelling.

Al balancerend vinden we de juiste weg.

Ik heb gezegd. 


\section{Referenties}

1. Saugstad OD. Room air resuscitation-two decades of neonatal research. Early HumDev 2005:81:111-116.

2. Stevens TP, Blennow M, Soll RF. Early surfactant administration with brief ventilation vs selective surfactant and continued mechanical ventilation for preterm infants with or at risk for respiratory distress syndrome. Cochrane Database Syst Rev 2004:(3):CDo03063.

3. Millar D, Schmidt B. Controversies surrounding xanthine therapy. Semin Neonatol 2004:9:239-244.

4. Ni Chonghaile $M$, Higgins $B$, Laffey JG. Permissive hypercapnia: role in protective lung ventilatory strategies. Curr Opin Crit Care 2005;11:56-62.

5. Weel van C, Gouma DJ, Lamberts SWJ. De bijdrage van klinisch wetenschappelijk onderzoek aan een betere patiëntenzorg. Ned Tijdschr Geneeskd 2003 Febr:147(6):229-233.

6. Avery ME, Mead J. Surface properties in relation to atelectasis and hyaline membrane disease. AMA J Dis Child 1959:97:517-523.

7. Morley R. Farewell V. Methodological issues in randomized controlled trials. Semin Neonatol 2000:5:141-148.

8. Schmidt B, Gillie P, Caco C, Roberts J, Roberts R. Do sick newborn infants benefit from participation in a randomized clinical trial ? J Pediatr 1999:134:151-155.

9. Discipline Report on (Bio)Medical and Health Sciences Research. Wetenschapsverkenningen. Raad voor Medische Wetenschappen van de Koninklijke Nederlandse Adademie van Wetenschappen. 1998.

10. Zorg voor onderzoek: Naar optimale voorwaarden voor wetenschappelijk onderzoek in universitair medische centra. Verslag discussiebijeenkomst 13 december 2000. Commissie Geneeskunde van de Koninklijke Nederlandse Akademie van Wetenschappen en Disciplineoverlegorgaan Medische Wetenschappen van de Samenwerkende Universiteiten. 2001.

11. Positionering academische ziekenhuizen. Brief van de ministers van Volksgezondheid, Welzijn en Sport en van Onderwijs, Cultuur en Wetenschappen. Tweede Kamer der Staten-Generaal 1998-1999. 26 275, nr. 1.

12. Kerrebijn KF. Naar een Erasmus Medisch Centrum. De tijd dringt. Afscheidsrede, Erasmus Universiteit Rotterdam 1994.

13. John Bell on behalf of the working group of Academy of Medical Sciences. Resuscitating clinical research in the United kingdom. BMJ 2003 Nov;327:10411043.

14. Steward PM. Improving clinical research: Failure to support clinical research now will cost human lives later. BMJ 2003:327:999-1000.

15. Clark J. Academic medicine: time for reinvention. Letters and summary of responses. BMJ 2004:328:45-49.

16. BMJ Publishing Group to launch an international campaign to promote academic medicine. BMJ 2003 Nov:327:1001-1002.

17. Wetenschapsbudget 2004: Focus op excellentie en meer waarde. Ministerie van onderwijs, cultuur en wetenschappen. 2004 
18. Wetenschapsbudget 2000: Wie oogsten wil, moet zaaien. Ministerie van Onderwijs. Cultuur en Wetenschappen. 2000.

19. Werkprogramma 2003 - 2005. Raad voor Medische Wetenschappen van de Koninklijke Nederlandse Akademie van Wetenschappen. 2002.

20. Weel van $C$. Kwaliteitsbeoordeling van medisch-wetenschappelijk onderzoek: voortaan ook op grond van maatschappelijke implicaties. Ned Tijdschr Geneeskd 2003:147:233-235.

21. Clark RH, Gerstmann DR, Jobe AH, Moffit ST, Slutsky AS, Yoder BA. Lung injury in neonates: causes, strategies for prevention, and long-term consequences. J Pediatr 2001;139:478-486.

22. Jobe AH, Bancalari E. Bronchopulmonary dysplasia. Am J Respir Crit Care Med 2001;163:1723-1729.

23. Bancalari E, Claure N, Sosenko IRS. Bronchopulmonary dysplasia : changes in pathogenesis, epidemiology and definition. Seminars in Neonatology 2003:8:63-71.

24. Jobe AH. Antenatal factors and the development of bronchopulmonary dysplasia. Seminars in Neonatology 2003:8:9-17.

25. Seidner SR, Jobe AH, Coalson JJ, Ikegami M. Abnormal surfactant metabolism and function in preterm ventilated baboons. Am J Respir Crit Care Med 1998:158:1982-1989.

26. Cogo PE, Zimmermann UI, Passavento R. Sacchetto E. Burighel A, Rosso F, Badon T, Verlato $G$, Carnielli VP. Surfactant kinetics in preterm infants on mechanical ventilation who did and did not develop bronchopulmonary dysplasia. Crit Care Med 2003:51:1532-1538.

27. Bunt JE. Surfactant phosphatidylcholine metabolism in preterm infants studied with stable isotopes. PhD thesis, Erasmus University Rotterdam 2000.

28. Janssen DJMT. Surfactant phosphatidylcholine metabolism in severe neonatal lung disease studied with stable isotopes. PhD thesis, Erasmus University Rotterdam 2003.

29. Poelma DL, Zimmermann $U$, Scholten $H$, Lachmann B, van Iwaarden JF. In vivo and in vitro uptake of surfactant lipids by alveolar type II cells and macropha. ges. Am J Physiol Lung Cell Mol Physiol 2002;283:L648-654.

30. Speer CP. Inflammation and bronchopulmonary dysplasia. Seminars in Neonatology 2003;8:29-38.

31. Koteçha S. Cytokines in chronic lung disease of prematurity. Eur J Pediatr 1996:155(2):S14-S17.

32. Noel-Georis I, Bernard A, Falmagne P, Wattiez R. Proteomics as the tool to search for lung disease markers in bronchoalveolar lavage. Dis Markers 2001;17(4):271-284.

33. Hirsch J, Hansen KC, Burlingame AL, Matthay MA. Proteomics: current techniques and potential applications to lung disease. Am J Physiol Lung Cell Mol Physiol 2004:287:L1-L23.

34. Rothen-Rutishauser BM, Kiama SG, Gehr P.A three-dimensional cellular model of the human respiratory tract to study the interaction with particles. Am J Respir Cell Mol Biol. 2005 Apr;32(4):281-289. 
35. Costeloe K, Hennessy E, Gibson AT, Marlow N, Wilkinson AR, for the EPICure Study Group. The EPICure study: outcomes to discharge from hospital for infants born at the threshold of viability. Pediatrics 2000:106:659-671.

36. Marlow N, Wolke D, Bracewell MA, Samara M, for the EPICure Study Group. Neurologic and developmental disability at six years of age after extremely preterm birth. N Engl J Med 2005;352:9-19.

37. Verhagen E, Sauer PJ. The Groningen protocol - euthanasia in severely ill newborns. N Engl J Med 2005:352:959-962.

38. Porter ME, Teisberg EO. Redefining competition in health care. Harv Bus Rev. 2004 Jun; $82(6): 64-76$.

39. Bakens zetten: Naar een Nederlands raamwerk van prestatie-indicatoren voor de gezondheidszorg. Ministerie van Volksgezondheid, Welzijn en Sport. Dec 2002.

40.Feenstra L. Peinzend over een universitaire klinische afdeling. Ned Tijdschr Geneeskd 1997 Dec;141(52);2579-2583.

41. Whitcomb ME. The most serious challenge facing academic medicine's insłitutions (editorial). Acad Med 2003:78:1201-1202.

42. The Academic Medical Center Working Group of the Institute for Healthcare Improvement. The imperative for quality: a call for action to medical schools and teaching hospitals. Acad Med 2003:78:1085-1089.

43. Watson RT. Rediscovering the medical school. Acad Med 2003:78:659-665.

44. Fincher RME, Simpson DE, Mennin SP et al. Scholarship in teaching: an imperative for the 21st century. Acad Med 2000:75:887-894. 
In Balans?..! 